\title{
Studies on virus infection of diseased Quercus robur (L) from forest stands in northern Germany
}

\author{
C Büttner, M Führling \\ Universität Hamburg, Institut für Angewandte Botanik, Abteilung Pflanzenschutz, \\ Marseiller Str 7, 20355 Hamburg, Germany
}

(Received 1 April 1995; accepted 2 November 1995)

\begin{abstract}
Summary - Virus-like symptoms such as distinct chlorotic lesions, ringspots and chlorotic mottle were observed on leaves of oak trees and seedlings (Quercus robur $\mathrm{L}$ ) growing at several forest stands and nurseries in north Germany. The same symptoms were induced on young oak seedlings after grafting. The causing agent was not transmissible by mechanical inoculation of plant sap to indicator plants. Investigations by serological means demonstrated that the agent of virus-like symptoms of oak is not related to tobacco mosaic virus, tobacco necrosis virus, brome mosaic virus and cherry leafroll virus, which have previously been detected in forest trees and soil of other forest ecosystems. Further studies with leaf tissue confirm the detection of double-stranded RNA (dsRNA) indicated at 1.5 to $2.0 \mathrm{kbp}$ in oak with and without symptoms, which leads to the hypothesis that the particles belong to the cryptic virus group.
\end{abstract}

Quercus robur (L) / ringspots / mottle graft-transmissible / virus / dsRNA

Résumé - Analyse d'une infection virale sur Quercus robur (L) dans les peuplements du nord de l'Allemagne. Des symptômes soupçonnés d'être d'originale virale, se caractérisant par des lésions chlorotiques distinctes, des taches annulaires et des marbrures, ont été observés sur des chênes (Quercus robur $L$ ) et sur leurs semis dans plusieurs forêts et pépinières du nord de l'Allemagne. L'agent causal a pu être transmis par greffage à de jeunes plants qui ont développé des symptômes caractéristiques de la maladie. Cet agent n'est pas transmissible par inoculation mécanique de sève à des plantes indicatrices. Les approches sérologiques ont montré que l'agent causal de cette maladie du chêne n'a aucun lien avec les virus de la mosaïque du tabac, de la nécrose du tabac, de la mosaïque du brome et de l'enroulement de feuilles du cerisier précédemment détectés sur les arbres et dans les sols d'autres écosystèmes forestiers. L'étude des tissus foliaires de chêne infecté confirme la présence d'ARN double brin de 1,5 à 2,0 kbp, quel que soit le niveau de développement des symptômes. L'ARN double brin mis en évidence est probablement dû à des virus appartenant au groupe des virus cryptiques.

Quercus robur (L) / taches annulaires / marbrure / transmission par greffage / virus / ARN á double brin (dsRNA) 


\section{INTRODUCTION}

Oak decline gained public attention when this economical and ecological important tree of German forests showed damage on a large geographic scale. Several biotic and abiotic factors have been suspected to contribute to the decline symptoms.

With respect to biotic factors, the involvement of fungal pathogens and insects in oak decline has often been described (Schopf, 1987; Kowalski, 1991; Kehr and Wulf, 1993), but there have been only a few studies on virus infection of oak trees (Nienhaus and Castello, 1989). Nienhaus (1975) observed leaf spots, mosaic and ringspots on oak (Quercus robur $\mathrm{L}$ ) in the Rhineland area. Horváth et al (1975) detected rod-shaped particles $(20 \times 300 \mathrm{~nm})$ characteristic of the Tobamovirus group in leaves with lateral reduction of the leaf blade and in sickleshaped leaves of Quercus cerris ( $\mathrm{L}$ ). Blattny and Prochazkova (1966) described chlorotic spotting and leaf deformations of oak trees in Czechoslovakia. The causal agent was graft- and aphid-transmissible and considered to be transmitted through seeds. Chlorotic ringspots, a characteristic symptom of virus infection, were described by Barnett (1971) and Kim and Fulton (1973) on Quercus marilandica ( $L$ ) and found to be associated with filamentous particles.

To date, mechanical transmission of viruses from oaks with virus-like symptoms - in contrast to symptomless ones - have not been successful. Nienhaus and Yarwood (1972) isolated tobacco mosaic virus (TMV) from oak leaves, independent of symptom development, by fractionating oak leaf sap through Sephadex and inoculated the sap on herbaceous hosts.

Chenopodium quinoa (Willd) plants developed symptoms after being inoculated with fractionated plant sap from symptomless, apparently healthy as well as symptomatic oak trees. Similarly, attempts to transmit virus isolates mechanically from other forest trees to healthy seedlings have usually failed except in a few cases listed by Nienhaus et al, 1990. Spruce and willow plants were successfully infected with tobacco necrosis virus (TNV); cherry leafroll virus (CLRV) was transmitted to birch, European beech and white ash seedlings. European beech was successfully inoculated with CLRV by stem-slashing.

Our investigations focused on the detection and parts of description of viruses or virus-like particles in diseased oak trees. Oak trees of north German forests and nurseries were marked and sampled. Some of these trees had degenerated twigs and suffered from a conspicuous loss of vigor, which could be characterized by a reduction of foliar and internodal length. Distinct from similar symptoms caused by other pathogens, insects or abiotic factors, three types of foliar symptoms were often observed (Büttner and Führling, 1993): small chlorotic lesions distributed over the entire leafblade (fig 1); chlorotic ringspots often

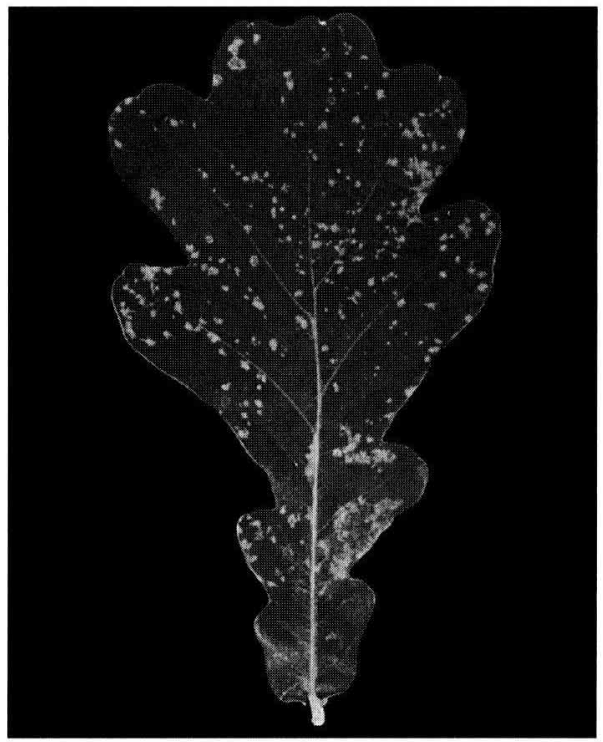

Fig 1. Chlorotic lesions scattered over the oak leafblade. 
restricted to the intercostal areas of leaves (fig 2); and chlorotic mottle advancing from the leaf base (fig 3 ).

\section{MATERIALS AND METHODS}

Sixteen oak trees with virus-like symptoms such as chlorotic ringspots, mottling or distinct chlorotic lesions were sampled once a month from June to September. Leaf and cambium tissues of branches were taken from these 15- to 60-yearold degenerating trees located in forest stands of northern Germany. Four hundred healthy 2to 4-year-old seedlings were collected from several nurseries. The plants were cultivated under field conditions. In addition, ten visually healthy and vital 60-year-old trees from natural forest stands were used as control plants. Several methods were used for virus detection.

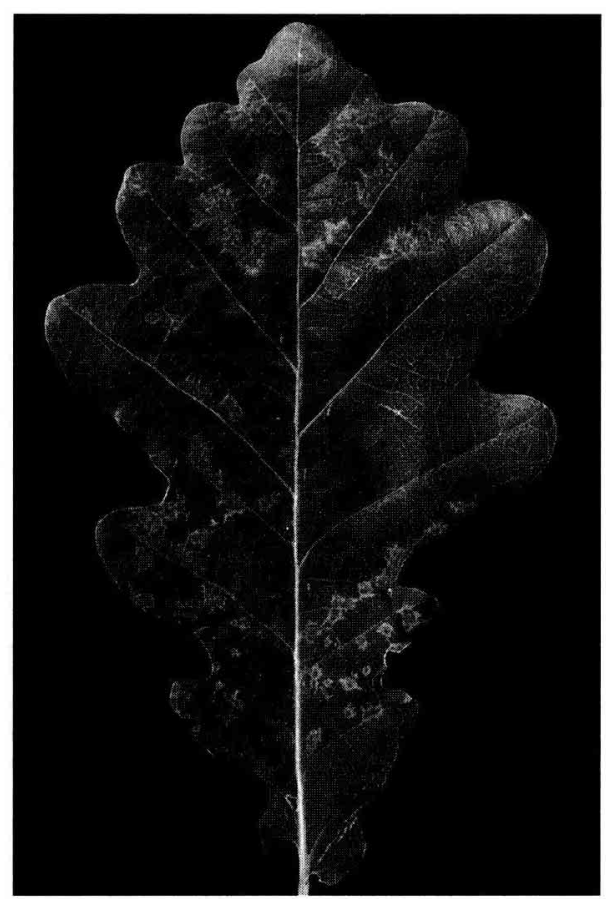

Fig 2. Chlorotic ringspots restricted to intercostal areas of the oak leaves.

\section{Mechanical transmission}

Leaf material was homogenized in a phosphate buffer $(0.2 \mathrm{M}, \mathrm{pH} 7.0)$. After adding celite as abrasive, this plant sap was inoculated on test plants such as Nicotiana tabacum var Xanthi, Samsun (L), Chenopodium quinoa (Willd), Datura stramonium $(L)$ and Lycopersicum esculentum $(L)$.

\section{Transmission by grafting}

From 1991 to 1994 , about 600 oak seedlings were grafted with chips and parts of branches which were cut from branches with leaves showing chlorotic ringspots or mottle. In reference 100 oak seedlings were grafted with plant material from healthy oak trees. As a suitable technique, whip grafting was combined with chip grafting (Führling and Büttner, 1995). Grafting wounds and cuts

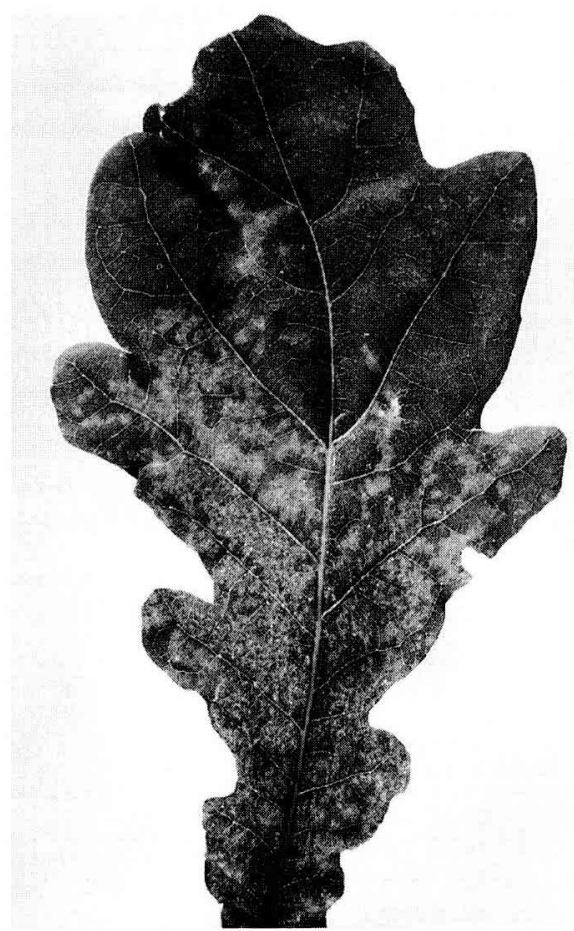

Fig 3. Chlorotic mottle developing from the oak leafbases over the leafblade. 
were covered with rubber tape (Fleicoband, Meyer) and wax (Rebwax WF, Meyer).

\section{Enzyme-linked immunosorbent assay (ELISA)}

The serological survey was conducted by using antisera to viruses that are known to occur in forest ecosystems, especially in oak trees. The test was carried out as a direct ELISA according to Koenig (1985) by using antisera to detect TMV, TNV, CLRV and brome mosaic virus (BMV).

\section{Detection of double-stranded (ds) RNA}

The detection of dsRNA is used in plant disease diagnosis when a virus etiology is assumed, but so far virus particles have not been isolated nor demonstrated by electronmicroscopical means (Valverde et al, 1990). The procedure for detecting dsRNA in oak leaves was adapted from Morris and Dodds (1979) as follows: Leaf tissue $(20 \mathrm{~g})$ was homogenized at low speed in a blender in $40 \mathrm{~mL}$ STE (200 mM sodium chloride, $100 \mathrm{mM}$ tris-hydrochloride, $2 \mathrm{mM}$ ethylendiamintetraacetic acid [EDTA], $\mathrm{pH} 7.1), 10 \mathrm{~mL}$ sodium dodecyl sulfate (SDS; $10 \%$ ), $0.4 \mathrm{~mL}$ mercaptoethanol, $30 \mathrm{~mL}$ STE-saturated phenol and $30 \mathrm{~mL}$ chloroform and well-shaken for $30 \mathrm{~min}$. Homogenates were centrifuged at $5000 \mathrm{~g}$ for 25 $\mathrm{min}$ and the aqueous phase containing cellular nucleic acids was recovered. Using the batch procedure (Morris et al, 1983), $2.5 \mathrm{~g}$ of Whatman CF-11 cellulose was directly added to the supernatant which was adjusted to $16 \%$ of ethanol. After the cellulose was collected by centrifugation and washed three times with $80 \mathrm{~mL}$ STEbuffered $16 \%$ ethanol to remove unbound impurities, the dsRNA was eluted in ethanol-free STE buffer, precipitated with ethanol and resuspended in a small volume of sample buffer containing $0.25 \%$ bromphenol blue and $30 \%$ glycerol in TAE (40 mM tris, $40 \mathrm{mM}$ glacial acetic acid, $2 \mathrm{mM}$ EDTA; pH 8.0). Nucleic acids were separated by electrophoresis in polyacrylamide gels (6\%). The nucleic acid structures were detected by the monoclonal antibody (J5) after blotting on an immobilizing membrane (Schönborn et al, 1991). The antibody $\mathrm{J} 5$ has a high specifity to dsRNA. DsRNA of reovirus was used as a reference. It was kindly provided by $\operatorname{Dr} \mathrm{N}$ Lukcas (University of
Düsseldorf, Physical Biochemistry Institute) as well as the antibody $\mathrm{J} 5$.

\section{RESULTS AND DISCUSSION}

Mechanical transmission of assumed viruses by plant sap did not lead to the development of virus-induced symptoms on the herbaceous indicator plants in any of the passages. Several reasons have to be discussed. The method is confined to mechanical transmissible viruses; those viruses which are only transmitted by vectors such as fungus, nematodes, insects or mites are not considered. Furthermore, it is conceivable that the selected indicator plants are no-host plants for the agent in oak trees although they are hosts for many viruses. Phenolic compounds in leaves of oaks might prevent virus transmission. The infection can also be inhibited due to temperature and light conditions while plants are inoculated or later while growing under greenhouse conditions. In addition, viruses may be irregularly distributed in woody hosts and difficult to detect (Grüntzig et al, 1994).

Grafting was a successful tool to transmit an agent inducing chlorotic ringspots, mottle or distinct chlorotic lesions in oak leaf tissue. Referring to control plants, none of the 100 seedlings being grafted with cuts from oaks without any previous described symptoms (figs 1-3) showed any virus-like symptoms. Symptoms were developed from 14 of 392 seedlings being grafted with cuts from diseased and virus-suspected oak trees. Leaf symptoms of treated plants developed earliest in the second vegetation period after grafting.

The pathogen in plant leaf sap of Quercus robur did not react with antisera having a specificity to TMV, TNV, CLRV or BMV. These pathogens are known to occur in forest ecosystems (Nienhaus and Castello, 1989). Büttner and Nienhaus (1989a, b) reported on virus contamination of soils and 
water in forested areas. The authors demonstrated that about $30 \%$ of the soil-root samples, taken at the stem base of conifers and deciduous trees, were contaminated by mechanically transmissible viruses belonging to the Potex-, Tobamo-, Tobacco necrosis- and Potyvirus group. The pathogens were isolated by bait-plant technique. Mechanically transmissible viruses of the Tobamo-, Potex- and Tombusvirus group could also be isolated from 39 of 66 samples taken from creeks, ponds and drainage ditches. Their detection succeeded by mechanical inoculation of an ultrafiltrate to herbaceous indicator plants. Our investigations did not lead to virus diagnosis by serological methods. It has to be taken into consideration that polysaccharides and phenolic compounds hamper the extraction of the viral proteins. Therefore, we applied a diagnostic trail by using the extraction and isolation of viral nucleic acids.

Most plant viruses are single-stranded (ss) RNA viruses which produce doublestranded (ds) RNA as an intermediate product during replication. Because dsRNA is consistently present in infected tissue but normally not found in healthy plants, dsRNA analysis can be of diagnostic value for plants suspected to be infected by ssRNA viruses (Jordan et al, 1983). In an attempt to demonstrate dsRNA in diseased Quercus robur with chlorotic ringspots and mottle, prominent dsRNA bands of 1.5 to $2.0 \mathrm{kbp}$ were obtained in all 26 investigated plants independant from symptom development (fig 4). For reliable detection of dsRNA in oak tissue, at least 20 $\mathrm{g}$ of leaf tissue was necessary for purification. Young seedlings that are grafted develop only few leaves. Therefore, $20 \mathrm{~g}$ of leaves was collected from several young plants as a sample of mixed leaves.

It should be taken into consideration that plants may contain the genome of dsRNA viruses such as reoviridae and cryptoviridae and that certain plant species and cultivars may contain nonviral (cellular) dsRNA

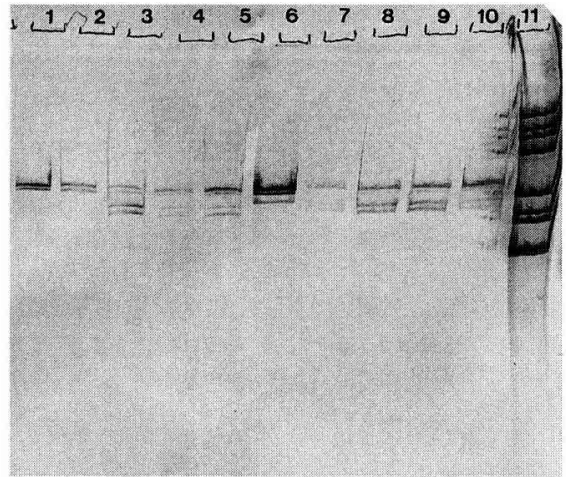

Fig 4. Used plant material for detection of dsRNA by immunoblotting. Slot 1 : visually healthy oak leaves without symptoms; slot 2: oak leaves showing chlorotic ringspots; slot 3: oak leaves showing mottling; slot 4: oak leaves indicating both mottling and ringspots; slot 5: visually healthy oak leaves without symptoms; slot 6 : visually healthy oak leaves without symptoms; slot 7 : oak leaves showing chlorotic ringspots; slot 8: oak leaves showing mottling; slot 9: oak leaves indicating both mottling and ringspots; slot 10: visually healthy oak leaves without symptoms; slot 11: reovirus dsRNA.

(Grill and Garger, 1981; Wakarchuk and Hamilton, 1985). However, dsRNA species obtained from oak tissue were much smaller than nonviral dsRNA which were observed by these authors. The dsRNA length of oak tissue (1.5-2.0 kbp) and their appearance as a double band point out to particles belonging to the cryptic virus group. Sixteen of 18 known cryptic viruses have previously been described in more detail (Dodds et al, 1984). The dsRNA genome consists of two to five segments. All viruses differ depending on the number and molecular weight of these segments. This is the first report on cryptic viruses from deciduous forest trees and further experiments are in progress. Thus, virus particles will be demonstrated by electronmicroscopic means and the capsid protein has to be isolated. It should be noted that cryptic viruses do not induce symptom development on the host plant. Their host range is narrow and they are transmitted 
only by seed and pollen (Milne, 1991). According to the symptom development on oak leaves and the possible transmission of an agent, the described symptoms of oak leaf tissue may be caused by viruses other than cryptic ones. Additional dsRNA structures which are related to the virus-like symptoms in oak trees should be isolated.

\section{ACKNOWLEDGMENTS}

The research project was financially supported by the German Government (Bundesminister für Forschung und Technologie, project no 0339337 $B)$ and then by the Deutsche Forschungsgemeinschaft (project no Bu 890 2/2). We are grateful to Prof Dr D Riesner at the University of Düsseldorf, Physical Biochemistry Institute for supplying the research laboratories on dsRNA.

\section{REFERENCES}

Barnett OW (1971) Mosaic of blackjack oak. Plant Dis Rep 55, 411

Blattny C, Prochazkova Z (1966) Beitrag zur Kenntnis der Virosen und virusverdächtigen Erkrankungen der Eichen (Quercus spp). Rev Roumaine Biol Ser Bot $11,39-42$

Büttner C, Führling M (1993) Beobachtungen zu virusbedingten Symptomen an erkrankten Stieleichen (Quercus robur $(\mathrm{L})$ - eine Abgrenzung zu ähnlichen, nicht virusbedingten Krankheitsbildern -. Nachrichtenbl Deut Pflanzenschutzd 45, 110-115

Büttner C, Nienhaus F (1989a) Virus contamination of soils in forest ecosystems of the Federal Republic of Germany. Eur J For Pathol 19, 47-53

Büttner C, Nienhaus F (1989b) Virus contamination of waters in two forest districts of the Rhineland area (FRG). Eur J For Pathol 19, 206-211

Dodds JA, Morris TJ, Jordan RL (1984) Plant viral doublestranded RNA. Annu Rev Phytopathol 22, 151-168

Führling M, Büttner C (1995) Transmission experiments of viruses to woody seedlings (Quercus robur and Sorbus aucuparia) by grafting and mechanical inoculation. Eur J For Pathol 25, 131

Grill LK, Garger SJ (1981) Identification and characterization of double-stranded RNA associated with cytoplasmatic male sterility in Vicia fabae. Proc Natl Acad SciUSA 78, 7043-7046

Grüntzig M, Fuchs E, Pfeilstetter E, Al Kai B, Otto F (1994) Untersuchungen zur Verteilung mechanisch übertragbarer Viren in Bäumen des Kern- und Steinobstes. Arch Phytopathol Pflanz 29, 217-248

Horváth J, Eke I, Gal T, Dezsery M (1975) Demonstration of virus-like particles in sweet chestnut and oak with leaf deformations in Hungary. Z PfIKrankh PfISchutz 82, 498-502

Jordan RL, Dodds JA, Ohr HD (1983) Evidence for viruslike agents in avocado. Phytopathology 73, 1130-1135

Kehr RD, Wulf A (1993) Fungi associated with aboveground portions of declining oaks (Quercus robur) in Germany. Eur J For Pathol 23, 18-27

Kim KS, Fulton JP (1973) Association of virus-like particles with a ringspot disease of oak. Plant Dis Rep 57, 1029-1031

Koenig R (1985) Antikörper im Dienste der Pflanzenvirologie. Nachrichtenbi Deut Pflanzenschutzd 37, 161-170

Kowalski T (1991) Oak decline. I. Fungi associated with various disease symptoms in overground portions of middle-aged and old oak (Quercus robur L). Eur $J$ For Pathol 21, 136-151

Milne R (1991) Cryptic virus group. In: Classification and Nomenclature of Viruses (RIB Francki, CM Fauquet, DL Knudson, F Brown, eds), Springer-Verlag, Vienna, 212-215

Morris TJ, Dodds JA (1979) Isolation and analysis of double-stranded RNA from virus-infected plant and fungal tissue. Phytopathology 69, 854-858

Morris TJ, Dodds JA, Hillman B, Jordan RL, Lommel SA, Tamaki SJ (1983) Viral specific dsRNA: diagnostic value for plant virus disease identification. Plant Mol Biol Rep 1, 27-30

Nienhaus $F$ (1975) Viren und virusverdächtige Erkrankungen in Eichen (Quercus robur und Quercus sessiliflora). Z PfIKrankh PflSchutz 82, 739-749

Nienhaus F, Yarwood CE (1972) Transmission of virus from oak leaves fractionated with Sephadex. Phytopathology $62,313-315$

Nienhaus F, Castello JD (1989) Viruses in forest trees. Annu Rev Phytopathol 27, 165-186

Nienhaus F, Büttner C, Hamacher J (1990) Virus infection of forest trees by mechanical transmission. $J$ Phytopathology 129, 141-150

Schönborn J, Oberstraß J, Breyel E, Tittgen J, Schumacher J, Lukàcs N (1991) Monoclonal antibodies to double-stranded RNA as probes of RNA structures in crude nucleic acid extracts. Nucleic Acids Res 19 , 2993-3000

Schopf A (1987) Vorläufige Ergebnisse entomologischer Unters-suchungen an erkrankten Eichen in Niederösterreich. Österreichische Forstzeitschrift $98,62-63$

Valverde RA, Nameth ST, Jordan RL (1990) Analysis of double-stranded RNA for plant virus diagnosis. Plant Dis 74, 255-258

Wakarchuk D, Hamilton RI (1985) Cellular double-stranded RNA in Phaseolus vulgaris. Plant Mol Biol 5, 55-63 